Article

\title{
The Effects of the Justice System on the Mental Health of Plaintiffs and Defendants
}

\author{
Miguel Clemente ${ }^{1, *}$ and Dolores Padilla-Racero ${ }^{2}$ \\ 1 Universidade da Coruna (Spain). Research Group in Criminology, Legal Psychology and Criminal Justice. \\ Department of Psychology; miguel.clemente@udc.es \\ 2 Universidade da Coruna (Spain). Research Group in Criminology, Legal Psychology and Criminal Justice. \\ Department of Psychology; dolores.padilla@udc.es \\ * Correspondence: miguel.clemente@udc.es
}

\begin{abstract}
This study aimed to assess the psychological effects of being processed by the justice system, either as a plaintiff or as a defendant. The sample consisted of 360 subjects, $32.8 \%$ defendants and $52.2 \%$ plaintiffs, residents in the Autonomous Community of Galicia (NW Spain). A lot of psychological test were administered. The results indicated significant differences between plaintiffs and defendants. The former were more pessimistic about the future, used poor strategies for protecting health, and had less empathy. In contrast, defendants had a more negative outlook on life, and in general more psychosomatic symptomology. Thus, both defendants and plaintiffs suffered health problems. Moreover, the group with the longest exposure to litigation had the worst deteriorated health. In conclusion, defendants were more pessimistic about the future, used poor strategies for protecting their own health, and showed less empathy. Likewise, plaintiffs had a more negative outlook on life, and on the whole presented more psychosomatic symptomology. Thus, both defendants and plaintiffs presented health problems. Moreover, the comparison between litigants and non-litigants showed health was more deteriorated in the former, but only in a few specific variables.
\end{abstract}

Keywords: defendant; Legal Psychology; litigation; mental health; plaintiff; user of the justice system.

\section{Introduction}

Anyone enduring endless litigation, in particular as a defendant or individuals at risk of losing a loved one (e.g., child custody disputes) will complain that long drawn-out litigation has seriously affected their health. Notwithstanding, to our knowledge, no study has assessed the impact on health, and in particular the mental health of user of the justice system itself. Though research has primarily focused on the victim's mental health, the impact of litigation itself has been overlooked. Moreover, from the victim's perspective, the term secondary victimization has been coined, and has prompted research by Gutiérrez de Piñeres-Botero, Coronel and Andrés-Pérez [1]. Victims of an offence often become victims of the justice system, and endure traumatic experiences which are product of the system itself. This phenomenon has been found to affect victims, families, friends, communities, carers, and aggressors.

From the aggressor's point of view, role theory as proposed by Symbolic Interactionism claims that individuals who commit an offence are branded delinquents or aggressors by the justice system, which significantly increases the probability of further conviction, even when no further offences are committed [2-3]. 
Many of the users of the justice system feel victimized by the system itself, be it as plaintiff or defendant, though the effect of harassment is often more acute in the former. Unfortunately, to our knowledge, there are no studies on harassment in the legal system with the exception of a few studies that bear some relation and will be examined below. In all societies there are disadvantaged groups, who are scorned by both society and the justice system. This is the working premise of Athwal and Burnett's study on racism [4]. The authors report on how members of specific alienated groups, primarily submerged in the underground economy, are "disappearing" due to low-level harassment of both society and the justice system itself that either fails to act or when it does, it is "low key" leaving criminals to go unpunished.

Strikingly, the justice system stigmatizes both litigating parties i.e., the plaintiff and the defendant, according to Stotzer's meta-analysis on 33 studies examining how the justice system's treats its users [5]. This study highlights that those who transgress the law suffer harassment, illegal detention, assault, and an overall lack of protection from the justice system since the perpetrators are the agents themselves of the justice system and law enforcement agencies. Similarly, victims also suffer harassment and discrimination from agents of the justice system and law enforcement agencies. In short, the law enforcement agencies and the justice system harass both victims and aggressors.

Moreover, the way in which victims are dealt with by the justice system affects their mental health. A good example is Bell, Street and Stafford's study on 1562 US Army reservists who had suffered sexual abuses in the army revealed that when they were treated fairly by the justice system and their statement was taken correctly and respectfully, the victim's mental health improved, in particular posttraumatic stress levels [6]. Conversely, mental health declined in those individuals who felt they had been treated disrespectfully by the justice system. A study undertaken on a prison population found similar results [7]. In short, we may hypothesize that in general the mental health of both crime victims and aggressors improves when they feel they have been treated appropriately by the justice system. Conversely, the inverse relationship on mental health occurs, if victims feel they have been treated inappropriately.

A plausible explanation for this discrimination, from a legal point of view, can be found in the concept of "legal consciousness" that consists of three elements: conscience, ideology, and hegemony [8]. In general, this theory draws a clear distinction between the theoretical concept of the law and its day-to-day functioning. Thus, the application of the law is claimed to be iatrogenic, i.e., though the law is supposed to defend the rights of victims, the individual application of the law often has adverse effects on victims. This author has raised the issue of why people are willing to allow a legal system to exist that preaches equality, but systematically produces inequality.

A further example of legal harassment is the "Perverse Norm", described by Fernández-Dols [9] who defined it as an explicit yet unattainable norm. The norm can only be complied with in ideal or exceptional circumstances [10]. This gives the police the opportunity to sanction anyone who does not comply with the norm when they violate it, even though everybody in the community expects everybody else to violate the norm, even though they know the law exists. For example, it is always easy to fine a restaurant or a pub as they always fail to comply with some laws or regulations, which makes them vulnerable to being fined by the police. Many perverse norms exist in an array of contexts in our day-to-day lives. These norms are usually imposed on all of the groups of a social subsystem or at least on the most socially disadvantaged groups disposed of authority through coercion by the dominant social order.

Notwithstanding, not all litigation is confined to Criminal law, and child custody disputes are a good examples where it is difficult to distinguish the victim from aggressor. Likewise, neither the term plaintiff should be used as synonymous to victim, nor defendant to aggressor. This ambiguity has spurred studies such as Gardner's [11] Parental Alienation Syndrome (PAS), that asserts the plaintiff is the aggressor, a claim that lacks any scientific empirical support [12-13].

Gardner [14] defines this syndrome as: "A childhood disorder that arises almost exclusively in the context of disputes over child custody. Its primary manifestation is the child's campaign of denigration against a parent, a campaign without justification. This results from the combination of programming (brainwashing) 
due to parental indoctrination and the child's own contributions to the vilification of the target parent. When physical or sexual abuse is present, animosity may be justified, and so the explanation of the child's hostility as parental alienation syndrome is inapplicable." (p.15). That is, Gardner believes that the syndrome occurs because the custodial parent (usually the mother) manipulates her children to perceive the noncustodial parent (usually the father) negatively and even makes those children invent nonexistent assaults and even sexual abuse by the noncustodial parent in order to get the justice system to prevent contact with that parent. This is an appealing idea, because it would allow children to achieve equal treatment and contact with both parents. And given the existence of a sexually imbalanced society that grants more privileges to mothers as caregivers of children, it defends fathers, who portray themselves as victims who furthermore struggle to prevent an unjust situation that keeps them from having contact with their children.

As PAS has no scientific basis, it use in the justice system is a travesty of Justice (and a capital one too). Legal decision-making in child custody litigation should be based on evidence-based science, and not on scientific gobbledegook. The use of unscientific theories raises ethical issues and concerns. PAS lacks the slightest hint of rigorous scientific methodology, thus any defence of PAS is unethical. It is rather odd that an article that adheres to scientific principles should be criticized in the defence of scientific gobbledegook. The application of PAS in judicial judgements in child-custody litigation (bearing in mind the lack of empirical tests) constitutes a cruel experiment without any safeguards or guarantees, and infringes the principle of patient consent to treatment, including those most vulnerable in society i.e., young children who the justice system should be committed to protect. Gardner provides no empirical data, but brags to his critics with suggestions that Parental Alienation Syndrome is comparable to Down Syndrome.

Notwithstanding, most studies refer to secondary victimization as the distress endured by a victim of an offence due to the negative psychological, social, legal, and financial impact of being processed by the justice system. This highlights the conflict of interest between the victim's legitimate but frustrated expectations, and institutional requirements. Victims feel the psychological trauma and physical pain caused by the offence is often misconstrued or ignored, which leaves them feeling defenceless and vulnerable. This undermines the victim's trust in the scientific community, and the perception that health care institutions and workers fail to meet their needs [15-17]. Occasionally, secondary victimization can be more traumatic than primary victimization [16-21].

Albertin [22] has pointed out that secondary victimization arises from the relationship between the victim and social institutions (social services, health care workers, the justice system, mass media, etc.), who occasionally fail to comply with ethical standards for the treatment of victims [20]. The terms Re-victimization or Secondary victimization refer to malpractice in the psychological or medical treatment of victims, mostly by unqualified or unscrupulous professionals [15].

The act of resorting to the justice system entails a stressful situation for the victim i.e., the forced reliving of the trauma endured during the incident. Moreover, the needs of victims for preserving their mental health (social support, understanding, regaining control and power over their lives, having a sympathetic ear, respect, privacy, etc.) often come into conflict with legal requirements (e.g., victims must give testimony in public, the burden of proof is on the credibility of the victim's testimony, compliance with rules and proceedings, victims forced to relive their traumas in order to challenge the testimony of their aggressors, etc.). Though the latter issue has been examined by Campbell [23], to our knowledge, no study has assessed the effects of the justice system on the stress levels of aggressors.

Besides suffering from severe psychological trauma, victims sustain physical injuries, and incur damages and financial loss resulting from the criminal offence. Moreover, the criminal offence is relived and perpetuated in the victim's mind. The feeling of powerlessness in the face of aggressor, as well as the fear of the assault recurring may trigger acute neurosis, prolonged episodes of anxiety, depression, etc. Psychological exhaustion may eventually lead to unfounded reactions intended to explain the traumatic event they have suffered, giving rise to feelings of guilt, and blaming themselves for the offence i.e., self-guilt. Moreover, society in general often stigmatizes the victim, and far from responding with solidarity and justice, victims are often treated unsympathetically, and 
viewed with mistrust and suspicion. Victimization leads to social alienation and social exclusion as well as increasing the risk of successive incidents of victimization, making the victim of the criminal offence even more vulnerable. In the short term victimization modifies the victims' habits and lifestyles, negatively affecting their domestic everyday lives, their interpersonal relationships, and their working and social lives.

Two types of justice system are said to safeguard against the impact of secondary victimization i.e., interactional justice and procedural justice [24-26].

Interactional justice refers to users being entitled to fair and polite treatment by the justice system, and the quality of interpersonal interaction during litigation [24, 26-28]. Interactional justice consists of two types: informational justice refers to the use of appropriate data to explain each phase of litigation, given that the extent to which individuals receive the adequate data concerning legal proceedings, they perceive they are being treated fairly, impartially, and equally. Thus, this underpins both veracity and justification. The second system, interpersonal justice, underscores impartial treatment received during litigation, respect for how the parties should be treated; fostering concern and sensitivity towards others i.e., empathy, education, and respect for others.

Procedural justice refers to the formal procedures enforced by an organization [24-27]. In South Korea a "Citizen Participatory Trial System" was implemented in 2008. The system is based on "Committees for the Citizens' Participation in the Judicial System", where citizens form part of juries in trials of female victims of sexual abuse. Legal proceedings designed to prevent secondary victimization entail installing all-women juries. Several authors have proposed a range of measures aimed at optimizing the efficacy of the system in order to improve the mental health of victims. For instance, Kim [29] proposed three measures to improve the system, with the third referring to strategies for preventing anxiety in victims whose identity has been disclosed in court, and the stressful situation of reliving their trauma during the trial. In practice, the aim was to design a system akin to plea-bargaining. One of the programs designed to prevent secondary victimization was the "Sexual Assault Nurse Examiner" or SANE. A study on 39 nurses who participated in the program found most thought the criminal justice system was the worst victimizer, followed by the health care system, and the legal system in general [30]. According to these professionals, the police generated most anxiety among victims, particularly because they are questioned with no sensitivity, and made victims feel guilty. Furthermore, the justice system often undermines the credibility of the victim, which leads to high levels of user dissatisfaction with the system.

The Korean system based on the recommendations of several authors has applied several improvements such as victim protection, a policy which has often been implemented without any empirical data to justify the practice [31]. Most of the studies on victimization and re-victimization in cases of sexual assault have been primarily assessed from an urban perspective, with few studies examining rural contexts [32].

Though most studies have employed a qualitative methodology, a few empirical studies have been undertaken [33-34]. In the former case, studies on gender violence found women who perceived negatively the justice system also tended to have intense feelings of secondary victimization caused by the system. In comparison, women who were less reliant on the criminal justice system and the police to prevent further assaults, expressed more satisfaction with the justice system. In addition, there was homeostatic phenomenon whereby women with more family support expressed more satisfaction with the police system.

In line with the findings of the present study, Calton and Cattaneo [35] concluded that litigation perceived as fair improved the mental health of victims, and victims stated they would use the justice system again should they be involved in another offence. Two variables were significantly modified by the perception of being treated fairly in litigation i.e., quality of life rose, and depression fell. It has been shown that these studies were not generalizable to victims of sexual offences [36].

As most studies have focused almost exclusively on the victim, and particularly on secondary victimization, this study aimed to assess the psychological effects of being processed by the justice system on both plaintiffs and defendants. Given that it is often difficult to distinguish the victim from the aggressor, in this study health was characterized in terms of plaintiff or defendant. Moreover, the 
psychosocial health of litigants was compared to non-litigants to determine differences. It was hypothesised both plaintiff and defendant would exhibit psychosocial health problems, and that the deterioration in health would be worse in defendants. A further conjecture was that the health of litigants (subjects actually involved in litigation) would be worse than the health of non-litigants.

\section{Materials and Methods}

\subsection{Participants}

The sample consisted of 360 participants; $53 \%$ women and $47 \%$ men; mean age 36 years (age range 18 to 81 years). A total of $52.2 \%$ of participants stated they had been involved in litigation as plaintiffs, and $32.8 \%$ as defendants (both questions were asked separately, the exclusion criterion being participants who were simultaneously involved in litigation both as plaintiffs and as defendants). The mean number of trials was 0.87 (minimum 0 , and maximum 7). All participants resided in the Autonomous Community of Galicia (N.W. Spain). The data was gathered through interviewers, who requested the collaboration, and obtained informed consent from individuals being processed by the law courts. Thus, the sample was incidental as it would have been unfeasible and complicated to obtain a random one. All participants were explained the aims of the study, and signed informed consent. Data were gathered from October to December 2018.

\subsection{Instruments}

A questionnaire was designed consisting of the following series of tests:

- Sociodemographic data, and data on the experience of being in contact with the justice system.

- Zimbardo's Time Perspective Inventory (ZTPI) is a multidimensional measure of time orientation, which allows individuals to fix their own past, present, and future. It can be classified as a personality test consisting of 56 items on a five-point Likert type response format. Both the validity and reliability indices were high. The Spanish version adapted by Diaz-Morales [37] was used to determine the following factors: past negative, present hedonist, future, positive past, and present fatalist. These factors correspond with those proposed by Zimbardo and Boyd [38]. A negative past expresses a pessimistic, negative and unfavorable view of the past; a present hedonist implies an attitude towards time and life based on pleasure, the pleasure in undertaking high-risk or high-adrenaline sports and exciting experiences; the future is linked to responsibility, achievement oriented, meeting deadlines, and concern for the consequences derived from different types of behavior; a past positive implied nostalgia and enthusiasm for the past; and the present fatalist revealed a desperate and defenceless attitude, a negative attitude towards the future, and life in general i.e., a lack of orientation in time.

- Levenson's I - E Locus of Control Scale. Levenson's scale [39] is a measure of the locus of control, which was initially designed by Rotter [40], and adapted and validated in Spanish by Perez-Garcia [41]. The Spanish version of Romero-Garcia and Perez [42] was used in this study. This scale measured each subject's internality (I) and externality (E) with two factors: internal and external. Moreover, externality was measured either in terms of "other powerful people" or chance. The scale consisted of 24 items scored on a six-point Likert type response format. Internality referred to individual personal beliefs about one's own skills, characteristics, attitude, and behaviour in determining success or failure in life i.e., being in control of one's destiny. In comparison, externality attributes success or failure in life to outside forces i.e., the belief that powerful people control their lives; whereas chance externality is the belief that luck, fate, or divine destiny determine life. Global externality encompasses both types of externality. Moreover, studies on the reliability and validity of the scale have obtained positives results [43-45]. 
- The Psychological Reactance Scale (PRS) of Hong and Page [44]. This concept was underpinned by Brehm's [46] claim that perceived threats to freedoms trigger a motivational impulse in people, which has been referred to as psychological reactance whereby individuals who perceive their freedoms are threatened or fear others may be lost believe that by acting unlawfully they are restoring their freedoms. Wortman and Brehm [47] described four components of reactance: expected freedoms, implied threat/the force of threat, importance of freedom, and implications for other rights. Hong and Page's [44] scale consists of two components: affective and cognitive, with 8 and 6 items, respectively. In this study the Spanish version of this scale, adapted by Pérez, San Juan, Bermudez and Sánchez [45] was used.

- Moos' Coping Strategies Scale (CSS). Moos views stress as a manifestation of the disequilibrium between external and internal demands as perceived by the individual, and the availability of resources for coping [48-49] Moos' Coping Responses Inventory (CRI) was adapted for Adolescents i.e., the CRI-Y [50-51]. In the present study the Spanish version of the CRI-Y), adapted by Ongarato, De la Iglesia, Stover and Fernandez-Liporace [52] was used. The original version of the questionnaire was composed of 48 items, grouped into 8 dimensions. The version used in this study consisted of four scales: coping for cognitive approximation, coping for behavioral approximation, coping for cognitive avoidance, and coping for behavioural avoidance. The psychometric properties of this scale have been corroborated [53].

- The Scale of Self-efficacy on Health, SHE [54]. The SEH consisted of 10 items scored on a fourpoint Likert type response format, all of the options were drafted by the authors. The scale was based on the Self-efficacy Tests of Baessler and Schwarzer [55] and Sanjuán, Pérez-García and Moreno [56] but only items on health issues were included.

- Symptom Checklist-90-Revised (SCL-90-R) Derogatis. The SCL-90-R is composed of 90 questions measuring several dimensions: Somatization, Obsessive-Compulsive, Interpersonal Sensitivity, Depression, Anxiety, Hostility, Phobic anxiety, Paranoid ideation, and Psychoticism. The global indices of psychosomatization were calculated using this checklist. The psychometrically tested [49-51] adapted Spanish version was used in this study [60].

\subsection{Procedure}

Having designed the questionnaire, a team of interviewers was responsible for collecting data from plaintiffs and defendants at the law courts of the four provinces of the Autonomous Community of Galicia (NW Spain). Once the data has been gathered, an Excel data matrix was created, prior to exporting it to the IBM SPSS-20 statistical package. Statistical $\mathrm{T}$ tests were performed to compare independent samples in the following groups:

- Subjects who had previously been in litigation as defendants (defendants) versus subjects who had never been in litigation as defendants (non-defendants).

- Subjects who had previously been in litigation as plaintiffs (plaintiffs) versus subjects who had never been in litigation as plaintiffs (non-plaintiffs).

- Subjects who were in litigation (litigants) versus subjects who were not in litigation (nonlitigants).

No reliability or validity tests on the instruments employed in this study were undertaken, given that the psychometric properties have been confirmed to be satisfactory by the empirical data.

\section{Results}

\subsection{Defendants versus non-defendants}

Initially, a statistics T-test was performed to compare defendants versus non-defendants. As shown in Table 1, significant results (a minimum bilateral confidence score of $95 \%$, that is, $\mathrm{p}<.05$ ) 
were found in a large number of variables: being negative (i.e., the scores for defendants were below the scores for non-defendants), in Present hedonist (do not enjoy present time); Future (were more pessimistic about the future); Present fatalist (obtained lower scores on perceiving the present as a problem); Global time perspective (more negative); External control by other powerful people (defendants rejected the belief that what happens to them in life depends on other powerful people); Global external control (defendants were globally less external than non-defendants); Affective and cognitive reactance (defendants did not like to recur in behaviours that led to problems); Self-efficacy in health (defendants were not efficacious at protecting their own health); Interpersonal sensitivity (lack mutual understanding); Depression (defendants were less depressed); Anxiety (less anxiety), Hostility (less hostility); Phobic anxiety (less phobic anxiety); Paranoid ideation (less paranoid ideation); Psychoticism (less), and GSI global psychosomatic indices (lower global psychosomatic indices). Moreover, defendants exhibited the highest global reactance scores. In short, globally defendants were pessimistic about the future, used poor strategies for protecting their own health, and exhibited less empathy and interpersonal sensitivity.

Table 1. T Test comparison of mean difference between defendants versus non-defendants

\begin{tabular}{|c|c|c|c|c|}
\hline \multirow[t]{2}{*}{ Variable } & \multirow[b]{2}{*}{$\mathrm{t}$} & \multicolumn{3}{|c|}{ Sig. } \\
\hline & & gl & (bilateral) & Mean \\
\hline Past negative & $-1,914$ & 350 & ,056 &,- 124 \\
\hline Present hedonist & $-3,152$ & 355 & ,002 &,- 204 \\
\hline Future & 3,573 & 354 & 001 & ,230 \\
\hline Past positive &,- 764 & 357 & ,446 &,- 046 \\
\hline Present fatalist & $-3,159$ & 357 & 002 &,- 194 \\
\hline Outlook on life/Time Perspective & $-2,064$ & 347 &, 040 &,- 072 \\
\hline Internal control &,- 690 & 355 & ,490 &,- 030 \\
\hline Chance external control & $-1,489$ & 356 & 137 &,- 077 \\
\hline Powerful others external control & $-2,686$ & 351 & ,008 &,- 162 \\
\hline Global external control & $-2,573$ & 351 &, 011 &,- 118 \\
\hline Affective reactance & $-2,194$ & 357 & 029 &,- 133 \\
\hline Cognitive reactance & $-3,638$ & 357 & ,001 &,- 230 \\
\hline Global reactance & $-3,309$ & 356 & ,001 &,- 176 \\
\hline Cognitive coping &,- 678 & 355 & ,498 &,- 039 \\
\hline Behavioural coping & 1,263 & 355 & 207 &, 084 \\
\hline Cognitive avoidance & $-1,198$ & 357 & 232 &,- 084 \\
\hline Behavioural avoidance &,- 884 & 356 & ,377 &,- 066 \\
\hline Self-efficacy on health & $-2,217$ & 356 & ,027 &,- 104 \\
\hline Somatization & $-1,549$ & 353 & 122 &,- 138 \\
\hline Obsessive-Compulsive & $-1,619$ & 357 & 106 &,- 150 \\
\hline Interpersonal Sensitivity & $-2,138$ & 355 & ,033 &,- 173 \\
\hline Depression & $-2,282$ & 356 & ,023 &,- 221 \\
\hline Anxiety & $-2,209$ & 357 & ,028 &,- 191 \\
\hline Hostility & $-4,015$ & 358 & 001 &,- 430 \\
\hline Phobic anxiety & $-1,902$ & 356 &, 058 &,- 128 \\
\hline Paranoid ideation & $-2,619$ & 356 & ,009 &,- 261 \\
\hline Psychoticism & $-3,171$ & 355 & ,002 &,- 224 \\
\hline GSI & $-2,613$ & 349 & 009 &,- 202 \\
\hline
\end{tabular}


Note: d.f.: degrees of freedom; sig.: significance.

\subsection{Plaintiffs versus non-plaintiffs}

As for the comparison between plaintiffs versus non-plaintiffs, the results in Table 2 show that plaintiffs perceived more negatively the future and the past positively, and obtained higher scores in present fatalist, chance external control (the belief that what happens in life depends on luck, fate, or divine destiny), both global affective and cognitive reactance, and psychoticism. Thus, plaintiffs were globally found to have a more negative outlook on life, and presented more psychosomatic symptomology.

Table 2. T Test comparison of the means of plaintiffs versus non-plaintiffs

\begin{tabular}{|c|c|c|c|c|}
\hline Variable & $\mathrm{t}$ & d.f. & $\begin{array}{c}\text { Sig. } \\
\text { (bilateral) }\end{array}$ & $\begin{array}{c}\text { Mean } \\
\text { difference }\end{array}$ \\
\hline Past negative &,- 409 & 350 & ,683 &,- 025 \\
\hline Present hedonist & 1,298 & 355 & , 195 & 080 \\
\hline Future & $-4,770$ & 354 & ,001 &,- 286 \\
\hline Past positive & $-3,414$ & 357 & ,001 &,- 194 \\
\hline Present fatalist & 2,044 & 357 & ,042 & 119 \\
\hline Outlook on life/Time Perspective & $-1,287$ & 347 & , 199 &,- 042 \\
\hline Internal control & $-1,763$ & 355 & , 079 &,- 073 \\
\hline Chance external control & 2,280 & 356 & ,023 &, 111 \\
\hline Powerful others external control & 1,638 & 351 & ,102 & ,093 \\
\hline Global external control & 2,307 & 351 & 022 & ,100 \\
\hline Affective reactance &, 518 & 357 & ,605 & ,029 \\
\hline Cognitive reactance & 3,628 & 357 & ,001 & ,216 \\
\hline Global reactance & 2,160 & 356 & ,031 & 109 \\
\hline Cognitive coping &,- 966 & 355 & ,335 &,- 052 \\
\hline Behavioural coping &,- 041 & 355 & ,967 &,- 002 \\
\hline Cognitive avoidance &,- 867 & 357 & ,387 &,- 057 \\
\hline Behavioural avoidance & 1,691 & 356 & ,092 & ,118 \\
\hline Self-efficacy on health & $-1,132$ & 356 & ,258 &,- 050 \\
\hline Somatization & ,252 & 353 &, 802 &, 021 \\
\hline Obsessive-Compulsive & 135 & 357 & 892 & 011 \\
\hline Interpersonal Sensitivity & 1,201 & 355 & 231 & ,091 \\
\hline Depression &,- 007 & 356 & ,995 &,- 000 \\
\hline Anxiety & 471 & 357 & 638 & ,038 \\
\hline Hostility & 911 & 358 & ,363 & ,093 \\
\hline Phobic anxiety & 1,716 & 356 & ,087 & ,108 \\
\hline Paranoid ideation & ,958 & 356 & ,339 & ,090 \\
\hline Psychoticism & 2,340 & 355 & ,020 & 156 \\
\hline GSI & 744 & 349 & 457, & 054, \\
\hline
\end{tabular}

Note: d.f.: degrees of freedom; sig.: significance.

\subsection{Litigants versus non-litigants}


As shown in Table 3, the comparison between subjects who at the time of data collection were not involved in litigation (non-litigants) versus subjects who were involved in litigation (litigants) revealed the latter scored lower on present hedonist, and on behavioral coping. Thus, the health of litigants deteriorated more than the health of non-litigants, but this was observed in only a few variables.

Table 3. $\mathrm{T}$ Test comparison of the means of litigants versus non-litigants

\begin{tabular}{|c|c|c|c|c|}
\hline Variable & $\mathrm{t}$ & d.f. & $\begin{array}{c}\text { Sig. } \\
\text { (bilateral) }\end{array}$ & $\begin{array}{c}\text { Mean } \\
\text { difference }\end{array}$ \\
\hline Past negative &,- 446 & 348 & 656 &,- 032 \\
\hline Present hedonist & $-2,382$ & 353 & 018 &,- 172 \\
\hline Future & 1,023 & 352 & ,307 & 073 \\
\hline Past positive & ,038 & 355 & ,970 & ,002 \\
\hline Present fatalist & 1,268 & 355 & ,206 & ,087 \\
\hline Outlook on life/Time Perspective &,- 222 & 345 & 824 &,- 008 \\
\hline Internal control & $-1,535$ & 353 & ,126 &,- 074 \\
\hline Chance external control &,- 882 & 354 & ,379 &,- 051 \\
\hline Powerful others external control & 824 & 349 & 410 & ,055 \\
\hline Global external control & ,081 & 349 & ,935 & ,004 \\
\hline Affective reactance &,- 795 & 355 & 427 &,- 053 \\
\hline Cognitive reactance &,- 600 & 355 &, 549 &,- 042 \\
\hline Global reactance &,- 814 & 354 & ,416 &,- 048 \\
\hline Cognitive coping &,- 603 & 354 &, 547 &,- 038 \\
\hline Behavioural coping & $-1,992$ & 354 & , 047 &,- 147 \\
\hline Cognitive avoidance & $-1,348$ & 356 & 179 &,- 103 \\
\hline Behavioural avoidance & $-1,703$ & 355 & ,090 &,- 140 \\
\hline Self-efficacy on health & ,022 & 354 & ,983 & ,001 \\
\hline Somatization &,- 468 & 351 & 640 &,- 046 \\
\hline Obsessive-Compulsive & $-1,299$ & 355 & ,195 &,- 133 \\
\hline Interpersonal Sensitivity &,- 733 & 353 & 464 &,- 065 \\
\hline Depression & $-1,394$ & 354 & ,164 &,- 149 \\
\hline Anxiety &,- 664 & 355 &, 507 &,- 064 \\
\hline Hostility & $-1,680$ & 356 & ,094 &,- 202 \\
\hline Phobic anxiety & 138 & 354 & 890 & ,010 \\
\hline Paranoid ideation & $-1,234$ & 354 & ,218 &,- 136 \\
\hline Psychoticism & $-1,681$ & 353 & ,094 &,- 132 \\
\hline GSI & $-1,339$ & 348 & 182 &,- 115 \\
\hline
\end{tabular}

Note: d.f.: degrees of freedom; sig.: significance.

\section{Discussion}

The results obtained are summarized in Table 4, variables that were not significant in any of the analyses were eliminated, and a negative sign was added if the defendant, plaintiff, and litigant groups obtained lower scores than the non-defendant, non-plaintiff, and litigant groups, respectively. Conversely, if the non-defendant, non-plaintiff, and non-litigants groups obtained lower scores, a positive sign was added. 
Table 4. Summary of results

\begin{tabular}{|c|c|c|c|}
\hline Variable & Defendants & Plaintiffs & Litigants \\
\hline \multicolumn{4}{|l|}{ Past negative } \\
\hline Present hedonist & - & & - \\
\hline Future & - & - & \\
\hline Past positive & & - & \\
\hline Present fatalist & - & + & \\
\hline Outlook on life/Time Perspective & - & & \\
\hline \multicolumn{4}{|l|}{ Internal control } \\
\hline Chance external control & & + & \\
\hline Powerful others external control & - & & \\
\hline Global external control & - & & \\
\hline Affective reactance & - & + & \\
\hline Cognitive reactance & - & + & \\
\hline Global reactance & + & + & \\
\hline \multicolumn{4}{|l|}{ Cognitive coping } \\
\hline Behavioural coping & & & - \\
\hline \multicolumn{4}{|l|}{ Cognitive avoidance } \\
\hline \multicolumn{4}{|l|}{ Behavioural avoidance } \\
\hline Self-efficacy on health & - & & \\
\hline \multicolumn{4}{|l|}{ Somatization } \\
\hline \multicolumn{4}{|l|}{ Obsessive-Compulsive } \\
\hline Interpersonal Sensitivity & - & & \\
\hline Depression & - & & \\
\hline Anxiety & - & & \\
\hline Hostility & - & & \\
\hline Phobic anxiety & - & & \\
\hline Paranoid ideation & - & & \\
\hline Psychoticism & - & + & \\
\hline GSI & - & & \\
\hline
\end{tabular}

Significant differences were found between defendants and non-defendants. Defendants were more pessimistic about the future, used poor strategies for protecting their own health, and showed less empathy. Likewise, plaintiffs also had health problems i.e., had a more negative outlook on life, and on the whole presented more psychosomatic symptomology. Thus, both defendants and plaintiffs presented health problems. Moreover, the comparison between litigants and non-litigants showed health was more deteriorated in the former, but only in a few specific variables. This underscored that a) being processed by the justice system leads to the usurers' deteriorated mental health, both for the plaintiff and the defendant; and b) the longer the exposure to the justice system (according to the number of trials), the greater the deterioration in health. Though defendants presented greater fluctuations in psychosocial health, and plaintiffs showed fewer effects, these were qualitatively more problematic. In short, the results corroborated the hypothesis that being processed by the justice system deteriorated the mental health of users.

The results of this study have corroborated the findings of Gutiérrez de Piñeres-Botero, Coronel and Andrés-Pérez [1], Palacio [61] as well as the studies of Shim and Shin [2] and Theimann [3] who analysed victims separately (in this study, the plaintiff), from the aggressor (in this study, the 
defendant). In short, the justice system affected the mental health of users of the justice system, be they plaintiffs or defendants.

One of the main limitations of this study was the small and incidental sample. This field of research covers very intimate and sensitive issues, and individuals are reluctant to collaborate providing data. Moreover, a third group of users of the justice system who were simultaneously plaintiffs and defendants, a common scenario in Family law, were not analysed. Thus further research is required to assess the effects of litigation on the mental health of users of the justice system who are simultaneously both plaintiff and defendant.

\section{Conclusions}

The results indicated significant differences between plaintiffs and defendants. The former were more pessimistic about the future, used poor strategies for protecting health, and had less empathy. In contrast, defendants had a more negative outlook on life, and in general more psychosomatic symptomology. Thus, both defendants and plaintiffs suffered health problems. Moreover, the group with the longest exposure to litigation had the worst deteriorated health.

Defendants were more pessimistic about the future, used poor strategies for protecting their own health, and showed less empathy. Likewise, plaintiffs had a more negative outlook on life, and on the whole presented more psychosomatic symptomology. Thus, both defendants and plaintiffs presented health problems. Moreover, the comparison between litigants and non-litigants showed health was more deteriorated in the former, but only in a few specific variables.

\section{References}

Author Contributions: The authors of this research have participated equally in all phases of the work: research design, data collection, data analysis, preparation of the manuscript, and revision thereof.

Funding: This research received no external funding.

Conflicts of Interest: The authors declare no conflict of interest.

\section{References}

1. Gutierrez de Piñeres-Botero, C.; Coronel, E.; Andrés-Pérez, C. Revisión teórica del concepto de victimización secundaria [Theoretical review of the concept of secondary victimization]. Liberabit 2009, 15(1), 49-58.

2. Shim, H; Shin, E. Peer-Group Pressure as a Moderator of the Relationship between Attitude toward Cyberbullying and Cyberbullying Behaviors on Mobile Instant Messengers. Telematics and Informatics 2016, 33(1),17-24.

3. Theimann, M. School as a Space of Socialization and Prevention. European Journal of Criminology 2016, 13(1), 67-91.

4. Athwal, $\mathrm{H}, ;$ Burnett, J. Investigated or Ignored? An Analysis of Race-Related Deaths since the Macpherson Report. Race \& Class 2014, 56(1), 22-42. DOI: 10.1177/0306396814531694

5. Stotzer, R.L. Law Enforcement and Criminal Justice Personnel Interactions with Transgender People in the United States: A Literature Review. Aggression and Violent Behavior 2014, 19(3), 263-77. DOI: 10.1016/j.avb.2014.04.012

6. Bell, M.E,; Street, A.E.; Stafford, J. Victims' Psychosocial Well-Being after Reporting Sexual Harassment in the Military. Journal of Trauma \& Dissociation 2014, 15(2), 133-52. DOI: 10.1080/15299732.2014.867563

7. Smith, B.V. Uncomfortable Places, Close Spaces: Female Correctional Workers' Sexual Interactions with Men and Boys in Custody. UCLA Law Review 2012, 59(6), 1690-745. 
8. Silbey, S.S. After Legal Consciousness. Annual Review of Law and Social Science. 2005, 1, 323-68. DOI:10.1146/annurev.lawsocsci.1.041604.115938

9. Fernández-Dols, J.M. Norma Perversa: Hipótesis Teóricas [Standard Perversa: Theoretical Hypothesis]. Psicothema 1993, 5, 91-101.

10. Oceja, V; Fernandez-Dols, J.M. El Reconocimiento de la Norma Perversa y sus Consecuencias en los Juicios de las Personas [Recognition of Standard Perversa and its Consequences in Trials of Persons]. Revista de Psicología Social 1992, 7(2), 227-39.

11. Gardner, R. Recent trends in divorce and custody litigation. Academy Forum 1985, 2, 3-7.

12. Clemente, M.; Padilla-Racero, D. Are children susceptible to manipulation? The best interest of children and their testimony. Children and Youth Services Review 2015a, 51, 101-7. DOI:

10.1016/j.childyouth.2015.02.003

13. Clemente, M.; Padilla-Racero, D. Facts speak louder than words: science versus the pseudoscience of PAS. Children and Youth Services Review 2015b, 56, 177-84. DOI:

10.1016/J.CHILDYOUTH.2015.07.005

14. Gardner, R.A. Legal and Psychotherapeutic Approaches to the Three Types of Parental Alienation Syndrome Families: When Psychiatry and the Law Join Forces. Court Review 1991, 28(1), 14-21.

15. Kreuter, E.A. Victim Vulnerability: An Existential-Humanistic Interpretation of a Single Case Study. Nova Science, New York, United States, 2006.

16. Landrove, G. La Moderna Victimología [New Victimology]. Tirant lo Blanch: Barcelona, Spain, 1998.

17. Soria, M.A. Psicología y Práctica Jurídica [Psychology and Legal Practice]. Ariel: Barcelona, Spain, 1998.

18. Berrill, K.T.; Herek, G. Hate Crimes: Confronting Violence against Lesbians and Gay Men. Sage: Los Angeles, United States, 1992.

19. Beristain, A. Nueva Criminología Desde El Derecho Penal y la Victimología [New Criminology and Criminal Law Since Victimology]. Tirant lo Blanch: Barcelona, Spain, 1994.

20. Beristain, A. Criminología y Victimología [Criminology and Victimology]. Leyer: Bogota, Colombia, 1999.

21. Wemmers, J.A. Victims in the Criminal Justice System: A Study into the Treatment of Victims and its Effects on their Attitudes and Behaviour. Kugler: New York, United States, 1996.

22. Albertin, P. Psicología de la victimización criminal. In Psicología Criminal [Criminal Psychology]; Soria, M.A.; Pearson: Madrid, Spain, 2006; pp. 245-76

23. Campbell, R. What Really Happened? A Validation Study of Rape Survivors' Hel-Seeking Experiences with the Legal and Medical Systems. Violence Victims 2005, 20(1), 55-68.

24. Greenberg, J.; Cropanzano, R. Advances in Organizational Justice. Stanford University Press: London, United Kingdom, 2001.

25. Latham, G. Work Motivation: History, Theory, Research, and Practice. Sage: New York, United States, 2006.

26. Vardi, Y.; Weitz, E. Misbehavior in Organizations: Theory, Research, and Management. Lawrence Erlbaum: New Yok, 2004.

27. George, R.; Brown, D. Leadership Processes and Follower Self-identity. Lawrence Erlbaum Associates: New York, United States, 2004.

28. Omar, A. Victimization, justice individualism-colectivism. Xalapa: Mexico, 2006. 
29. Kim, I.H. Legal and Institutional Measures to Reform Participatory Trials for Sex Crime Cases. Asian Women 2015, 31(2), 53-84.

30. Maier, S.L. Sexual Assault Nurse Examiners' Perceptions of the Revictimization of Rape Victims. Journal of Interpersonal Violence 2012, 27(2), 287-315. DOI: 10.1177/0886260511416476

31. Lee, J. Issues Over Legislation Improving the Criminal Justice System Focusing on Crime Victims. Korean Criminological Review 2014, 25(2), 1-25.

32. Annan, S.L. "It's not just a job. This is where we live. This is our backyard": the experiences of expert legal and advocate providers with sexually assaulted women in rural areas. Journal of the American Psychiatric Nurses Association 2011, 17(2), 139-47. DOI: 10.1177/1078390311401024

33. Aranda-López, M.; Montes-Berges, B.; Castillo-Mayén, M.R.; Higueras, M. Percepción de la segunda victimización en violencia de género [Perception of secondary victimization in gender violence]. Escritos de Psicología 2014, 7(2), 11-8. DOI: 10.5231/psy.writ.2014.1502

34. Patterson, D. The Linkage Between Secondary Victimization by Law Enforcement and Rape Case Outcomes. Journal of Interpersonal Violence 2011, 26(2), 328-47. doi: 10.1177/0886260510362889

35. Calton, J.; Cattaneo, L.B. The Effects of Procedural and Distributive Justice on Intimate Partner Violence Victims' Mental Health and Likelihood of Future Help-Seeking. Am J Orthopsychiatry 2014, 84(4), 329-40. DOI: 10.1037/h0099841

36. Laxminarayan, M. Procedural Justice and Psychological Effects of Criminal Proceedings: The Moderating Effect of Offense Type. Social Justice Research 2012, 25(4), 390-405. DOI: 10.1007/s11211012-0167-6

37. Diaz-Morales, J.F. Estructura factorial y fiabilidad del Inventario de Perspectiva Temporal de Zimbardo [Factorial Structure and Reliability Inventory Zimbardo Time Perspective]. Psicothema 2006, 18(3), 565-71.

38. Zimbardo, P.G.; Boyd, N. Putting Time in Perspective: A Valid, Reliable, Individual-Differences Metric. J Pers Soc Psychol 1999, 17(6), 1271-88.

39. Levenson, H. Multidimensional Locus of Control in Psychiatric Patients. J Consult Clin Psychol. 1973, 41, 397-404.

40. Rotter, J.B. Generalized Expectancies for Internal versus External Control of Reinforcement. Psychological Monographs 1966, 80, 609.

41. Perez-Garcia, A.M. Dimensionalidad del constructo "Locus of Control" [Dimensionality of the construct “Locus of Control”]. Revista de Psicología General y Aplicada 1984, 39, 471-88.

42. Romero-García, O.; Perez, I. Escala Levenson Locus de Control. Análisis Factorial en Venezuela [Levenson Scale Locus of Control. Factor Analysis in Venezuela]. Universidad de Los Andes: Merida, Venezuela, 1985.

43. Hong, S.; Ostini, R. Further evaluation of Merz's Psychological Reactance Scale. Psychological Reports 1989, 64, 707-10.

44. Hong, S.; Page, S. A Psychological Reactance Scale: Development, Factor Structure and Reliability. Psychol Rep. 1989, 64, 1323-26.

45. Perez-Garcia, A.M.; Sanjuan, P.; Bermudez, J.; Sanchez, A. Perfiles de Personalidad y Feedback de Tarea: Análisis del Rendimiento, la Frecuencia Cardíaca y las Atribuciones Causales [Personality Profiles and Feedback of Task Performance Analysis, Heart Rate and Causal Attributions]. Revista de Psicología General y Aplicada 2002, 55, 317-35.

46. Brehm, J.W. A Theory of Psychological Reactance. Academic Press: New York, United States, 1966. 
47. Wortman, C.B.; Brehm, J.W. Responses to Uncontrollable Outcomes: An Integration of Reactance Theory and the Learned Helplessness Model. Advances in Experimental Social Psychology. 1975, 8, 277-336.

48. Frydenberg, E. Adolescent coping. Theoretical and research perspectives. Routledge: London, United Kingdom, 1997.

49. Lazarus, R.S. Emotion and Adaptation. Oxford University Press: New Cork, Irland, 1991.

50. Moos, R.H. Coping Responses Inventory-Adult Form. Psychological Assessment Resources: Odessa, United States, 1993.

51. Moos, R.H. Development and Application of New Measures of Life Stressors, Social Resources and Coping Responses. European Journal of Psychological Assessment 1995, 11, 1-13.

52. Ongarato, P.; De la Iglesia, G.; Stover, J.B.; Fernandez-Liporace, M. Adaptación de un inventario de estrategias de afrontamiento para adolescentes y adultos [Coping Responses Inventory: An Adaptation to Adolescent and Adult Population]. Anuario de Investigaciones de la UBA. 2009, XVI, 383-91.

53. Rial-Boubeta, A.; De la Iglesia, G.; Ongarato, P.; Fernández-Liporace, M. Dimensionalidad del Inventario de Afrontamiento para adolescentes y universitarios [Dimensionality Coping Inventory for Teenagers and College]. Psicothema 2011, 23(3), 464-474.

54. Gandoy, M.; Clemente, M.; Gomez-Cantorna, C.; Gonzalez-Rodriguez, R.; Reig-Botella, A. Selfefficacy and health: The SEH scale. American Journal of Health Behavior 2016, 40(3), 389-95. DOI: http://dx.doi.org/10.5993/AJHB.40.3.11

55. Baessler, J.; Schwarzer, R. Evaluación de la Autoeficacia: Adaptación Española de la Escala de Autoeficacia General [Evaluation of the Self-efficacy: Spanish Adjustment of the Scale of General Self-efficacy]. Ansiedad y Estrés 1996, 2, 1-8.

56. Sanjuán, P.; Pérez-García, A.M.; Bermudez-Moreno, J. Escala de autoeficacia general: datos psicométricos de la adaptación para población española [General Self-efficacy Scale: Psychometric Adaptation for Spanish Population Data]. Psicothema 2000, 12(2), 509-13.

57. Derogatis, L.R.; Rickels, K.; Rock, A.F. SCL-90 and MMPI. Step in validation of a new self-report scale. Br J Psychiatry 1976, 128, 280-9.

58. Derogatis, L.R.; Cleary, P.A. Confirmation of Dimensional Structure of SCL-90. Study in ConstructValidation. J Clin Psychol. 1977a, 33(4), 981-9.

59. Derogatis, L.R.; Cleary, P.A. Factorial invariance across gender for primary symptom dimensions of SCL-90. British Journal of Social and Clinical Psychology 1977b, 16, 347-56.

60. Derogatis, LR. SCL-90-R. Cuestionario de 90 síntomas [Symptom Checklist 90 Revised]. TEA: Madrid, Spain, 2002.

61. Palacio, M. Contribuciones de la victimología al sistema penal [Victimology contributions of the criminal justice system]. Jurídicas Gustavo Ibáñez: Bogota, Colombia, 2001. 